\title{
Effectiveness Of Outdoor Learning Optimization Program In Learning Social Studies
}

\author{
Sukma Perdana Prasetya ${ }^{1^{\star}}$, Nuansa Bayu Segara ${ }^{2}$ Ali Imron ${ }^{3}$ \\ ${ }_{1}^{1}$ Program Studi Pendidikan IPS, Universitas Negeri Surabaya, Indonesia \\ 2 Program Studi Pendidikan IPS, Universitas Negeri Surabaya, Indonesia \\ e-mail: sukmaperdana@unesa.ac.id, nuansasegara@unesa.ac.id, aliimron@unesa.ac.id
}

\begin{abstract}
Outdoor learning is potential to expose social and natural phenomena related to social studies. However, the social studies teachers seldom to practice outdoor learning on certain occasions. This article has two aims. First, interpreting social studies teacher perspective about the simulation of an outdoor learning laboratory. Second, explain the teacher's obstacle if they are practicing outdoor learning in the school. Step of the research consist of 1) in service-learning 1;2) on the job learning; 3) in service-learning 2. The participants of this study involved 20 secondary high school active teachers of social studies in Surabaya. The data collecting technique used in this study is a questioner to measuring teacher's perspectives about the outdoor learning simulation in Surabaya, Sidoarjo, Mojokerto, Jombang, Tuban. Then, interview guidelines were used to perceive the data about teacher's obstacles to practice outdoor learning programs. The data analysis technique for examined teachers' perspectives is the percentage and discriminant statistics. The result of this study confirms that learning outdoor program offers a positive outcome. That is, 1) integrity while the social studies learning, extending social studies content, and helpful for difficult content; 2, Motivation improvement, attention and provide the student concrete experience; 3) Social studies learning to be fun, effective, and contextual. However, Social studies teachers assume laboratory outdoor activity is not efficient and hard to do, because they need a big fee, lengthy time, and require teachers' field experience for dominating social studies content.
\end{abstract}

Keywords: Outdoor Learning; Social Studies Learning; Outdoor Laboratory

\section{Introduction}

Learning is a process that lasts a lifetime, from the beginning to the end of life. The process of interaction with the environment greatly influences the learning experiences and cognitive growth (Amineh \& Asl, 2015; Bakhurst, 2015; Churcher, Downs, \& Tewksbury, 2014). The environment plays important role for humans' intelligence and their growth. Marcus (Loebach, 2004) claims that "humans are more affected by the environment than others. The stimuli that humans receive from the environment influences their growth and learning process in physical, cognitive, social and emotional.It is also very impossible to think of humans as entities that are separated from their environment.

A human being is at the center of his environment and is an element of the environment itself. Therefore, humans are influenced by their environment and affect their environment with their activities. Thus, the environment and interrelated behaviors influence understanding and behavior with various abilities possessed (Acar, 2013). Learners' experiences with nature and the social environment appear in three types of uses, namely: direct, indirect and symbolic or imaginary. The formation of the learner's personality and character is connected to these three levels of experience and three modes of learning (cognitive, emotional, moral). Cognitive development refers to thinking and problem solving skills; emotional maturity focuses on the emergence of feelings and emotions; Moral development emphasizes the appearance of values, benefits and moral aspects (Castro \& Knowles, 2015; Kellert, 2002)

\footnotetext{
* Corresponding author.

Received 30 July 2019; Accepted 29 June 2020; Available online 20 June 2020

(C) 2020 JPI. All Rights Reserved
} 


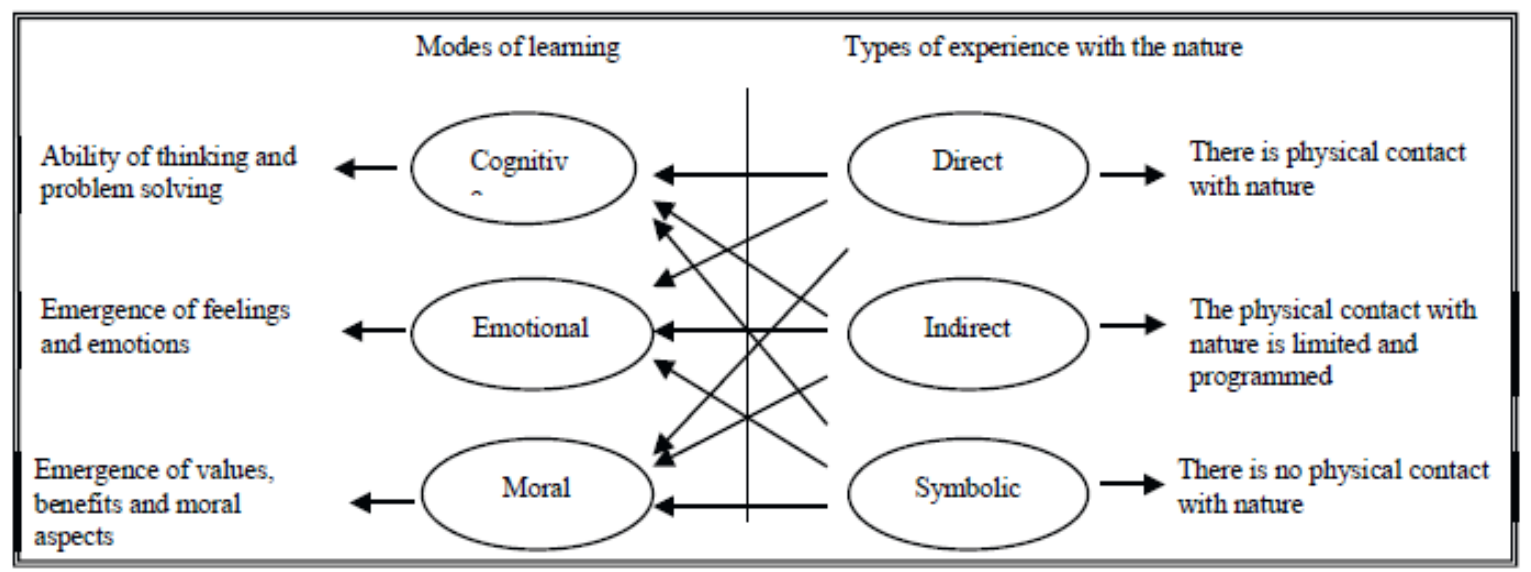

Figure 1. Types of Experiences in Nature and Learning Models

Three types of experiences contribute to students' cognitive, emotional and moral learning modes. Of the three experiences, one that offers many opportunities is direct experience. That's because it allows learning by touching, seeing, hearing and experiencing it. To learn about the environment, students need to actively utilize and explore the environment directly (Francis, 2017).

One important theoretical foundation of this research is based on John Dewey's "learning by doing" process that is applied to outdoor learning. Dewey said by applying the theory of learning experiences, it optimally helps students to open their access to the development of progressive knowledge, so that it will open up the possibility of students contributing to their environment (Dewey, 1951). Another theoretical concept to support this research is based on Kolb (1984), experiential learning process, which reveals four stages in learning: 1) Concrete experiences are followed by 2) Reflections on these experiences independently. Then stage 3) Abstract conceptualization, and 4) Active experiments to construct concepts from previous experiences for other concrete experiences. Learning with outdoor laboratories enters into the stage of understanding and constructing problems through concrete experiences outside the room. This activity is very important in social studies learning that does require concrete learning experiences ((Singer, 2003).

Outdoor learning in the natural environment is an attitude that aims to supply experiential learning activities, work together and knowledge about nature, and be integrated into subjects such as science and Social Studies. According to (Prasetya, 2018) Outdoor learning activities can be integrated in social studies learning. Outdoor learning will shape understanding by building and reconstructing knowledge from experience (Karppinen, 2012). Environmental learning resources directly can increase the level of accuracy of information, because students can feel direct experience and can use all the senses (seeing, touching, smelling, feeling) to interact with that environment. It is possible for learning activities to be more attractive to students considering the environment presents a variety of varied learning resources (Brophy \& Alleman, 2009). The variety of learning resources by utilizing environmental conditions can be an important component as an effort to prepare learning societies and human resources to respond to global challenges. Lots of knowledge and values that can be obtained in the environment as a learning source.

The outdoor laboratory in Social Studies is a place for long-term study of physical, social and cultural phenomena that can be studied by all fields of Social Studies (Henderson \& Aginsky, 1941). The outdoor laboratory must now have a greater role, especially to bring social knowledge into realityfor students who are in the information search stage. The laboratory must be able to be a source of learning, to add concrete experiences and the construction of learning knowledge (Kolb, 1984).

The results of previous research studies reveal several studies that examine laboratories as learning resources. Byrd, Haque, Tai, McLellan, \& Knight, (2007) conducted laboratory designs as environmental learning by making the "water garden" a laboratory for environmental 
learning. As a result students learn about the experience of nature phenomena and also social interaction with local communities. Other research results reveal that there is a consistency of affective responses to enthusiasm in the environment outside the classroom. These findings indicate that the environment influences the affective response to short walks and shows that the affective state experienced during walking is related to the theoretical determinants of physical activity (Focht, 2009). Other results show that when learning in outdoor laboratories runs most students are able to follow each stage of the experiment. However, some of them misinterpret the results and conclusions. Types of activities outside the classroom are very important to promote meaningful learning in children (Boaventura, Faria, Chagas, \& Galvão, 2013). Research in Indonesia that examines the environment and used as an outdoor laboratory was conducted by Sujarwo, Samsi, \& Wibawa, (2017)who made the Gembira Loka zoo as a laboratory outside the classroom. The focus of this research is to design a model that is equipped with activity guides, learning guides, and study tour guide materials in outdoor laboratories.

From the results of these studies, it can be concluded that outdoor laboratory is very important because students can encounter natural phenomena directly, and also interactions with local communities will occur and make a good experience for students. Psychologically, outdoor laboratories support students' enjoyment in learning, trigger the curiosity in learning phenomena from their source directly, will make them enthusiastic. According to the classification of experience (Cone of Experience) in an effort to use media as a tool, direct experience occupies the most concrete level of experience (Dale, 1969; Prasetya, 2014). Through outdoor laboratories students can really see, touch, smell, hear and feel directly the subject matter.

Outdoor laboratories become an integrated part of social studies learning, considering social studies material studies various interactions of aspects of the natural and social aspects of society so as to realize an environmental-social interaction on the surface of the earth (Westley, Goebey, \& Robinshon, 2010). The development of outdoor laboratories for social studies has become a demand along with developments in learning and changes in the education curriculum that requires students to be actively involved in conducting activities through hands-on practical experience.

Outdoor laboratories support the achievement of student competencies in social studies subjects (Webster, M. \& Sell, 2014). In this context, outdoor laboratories are a source of social studies learning activities, both done by teachers and students where miniature social life can be seen (Cook, 2008). Outdoor laboratories are used to support the achievement of social studies subject competencies, teachers and students can analyze various social phenomena by linking them to the material in school. Through this method, social studies learning becomes "more real", where the learning objectives of students are expected to have an understanding of human interaction and the environment, including responsiveness to various social problems so as to enhance tolerance and brotherhood between humans, it will certainly be easier to build.

The findings of the research (Campbell \& Bohn, 2018), pointed out that the existence of laboratories outdoor can encourage activities centered on the development of specific skills such as the formation of a scientific attitude, motor skills, process skills, and specialized development of interest to carry out research, research environment and interest to study integrated Social Studies. Research (Levitt \& List, 2017) has shown that outdoor laboratories can motivate learners' interests, and make Social Studies learning activities relevant and contextual.

The focus of this study differs from previous studies that have applied directly to the learning process (Boaventura et al., 2013; Byrd et al., 2007; Fisher, Harrison, \& Henderson, 1988; Halim, 2009; Sujarwo et al., 2017) and learners are the subject of research. While this study focuses on teaching teachers how to conduct an social studies learning activity by utilizing an outdoor laboratory in northeast Java. Teachers who have followed the demonstration of this activity will provide insights and reflect on the constraints in learning this outdoor laboratory. The results can serve as a background and reference for the development of Social Studies outdoor laboratory learning activities. A major highlight of this research is the 
Social Studies teacher who plays a role in projecting to influence attitudes, awareness, knowledge and field experience in practicing outdoor laboratory learning. Hopefully, after the demonstration finished, the teacher has an idea in conducting outdoor learning laboratory in East Java.

The problem of this research is based on the results of the initial study interview with social studies teachers in Surabaya. Most teachers in Surabaya claimed that it was not optimal to make the environment in East Java an outdoor laboratory in social studies learning (table 1). Social studies teachers in Surabaya often do tours but have not made it into an outdoor laboratory as a source of social studies learning. Social studies teachers rarely bring their students to see the real environment condition as a social studies learning laboratory. This condition results in social studies material which is still based on textbooks that are not necessarily relevant and contextual in accordance with reality on the ground. This condition will affect the learning process in schools because social studies subjects for certain materials that are abstract, require learning resources that are concrete and contextual.

Supposedly, social studies learning should not be boring and end up with material in the classroom. Social studies teachers need to broaden the understanding of the material through the study of phenomena that occur directly in the field as a result of interference with human activities. For this reason, it is necessary to have an outdoor learning laboratory that explores the potential of the real environment as a dynamic social studies material. For this reason, it is very urgent to increase the mastery of integrated social studies material for social studies teachers. One effort to improve the acquisition of integrated social studies material is to learn through the use of outdoor learning laboratories.

Table 1. Use of Outdoor Laboratories by Teachers in the City of Surabaya

\begin{tabular}{lcccc}
\hline \multirow{2}{*}{ Question } & \multicolumn{3}{c}{ Teacher Response (\%) } \\
\cline { 2 - 5 } & $\begin{array}{c}\text { Has never } \\
\text { been }\end{array}$ & Ever & Rarely & Often \\
\hline $\begin{array}{l}\text { Use of the Environment as a Laboratory } \\
\text { in East Java }\end{array}$ & 70 & 25 & 5 & 0 \\
$\begin{array}{l}\text { Fieldtrip Outside East Java } \\
\text { Equipping Students with Learning }\end{array}$ & 0 & 5 & 15 & 80 \\
Guidelines when Fieldtrip study & 75 & 15 & 5 & 5 \\
\hline
\end{tabular}

Table 1 shows that most social studies teachers in Surabaya have never used the environment in East Java as a social studies laboratory. However, most of them often do field trip Social studies outside East Java, it's just that they are not provided with study guidelines when doing the field trips.

The laboratory becomes an integrated part in social studies learning (Westley et al., 2010). The development of social studies laboratories has become a demand in line with developments in learning and changes in the education curriculum that requires students to be actively involved in carrying out activities through hands-on practical experience. (Campbell \& Bohn (2018), emphasized that the existence of laboratories must encourage the occurrence of activities that are centered on the development of certain skills such as the formation of scientific attitudes, motor skills, process skills, and specifically the development of an interest in conducting investigations, environmental research and an interest in studying integrated social studies science.

The selection of areas for outdoor learning laboratory locations in the region itself, namely the northern provinces of East Java (Surabaya, Sidoarjo, Mojokerto, Jombang, and Tuban) is not only more efficient in terms of funding and time, but also related to the implementation of contextual learning. This learning will be more meaningful by using existing learning resources and / or natural media around where you live (East Java) rather than exploiting the potential that exists in other provinces. Based on the description above, the North East Java Region is chosen as an area planned as an Outdoor learning laboratory for social studies subjects. 
Based on some of the problems discussed earlier that teachers have not optimized the environment as a source of learning, and also students' interest in social studies learning is low, it is very necessary to introduce outdoor laboratories to social studies teachers so that teachers can find out how fun and effective the use of outdoor laboratories is. The purpose of this article is to find out how the effectiveness and perception of teachers in the implementation of outdoor learning laboratories in social studies learning.

\section{Metode}

This research uses a descriptive method. The stages of research activities that have been carried out include: 1) in service learning model 1 (Brainstorming and providing training on the role of outdoor learning laboratories for social studies learning), 2) on the job learning (field observation activities and mentoring), and 3) in service learning 2 (the teacher presents the results of the field observation report). After the teachers carry out all three stages, the teacher is asked to respond. This study involved 20 junior high school social studies teachers in the city of Surabaya. Data collection techniques used were a questionnaire with a Likert scale and interview guidelines. Distribution of questionnaires to the teachers to identify how the response of satisfaction and difficulties of teachers in following the Social studies outdoor laboratory observation activities in the northern part of East Java. The data analysis technique used is percentage and discriminant statistical techniques. Percentages were used to determine teacher responses and discriminant statistics were performed to analyze teacher perceptions on the influence of outdoor learning activities on social studies learning. Discriminant analysis also functions to identify, classify and differentiate data. The locations used as outdoor learning laboratories are in table 2 below.

Table 2. Outdoor Laboratory Location and Conformity with Social Studies Content

\begin{tabular}{|c|c|c|}
\hline No & Location & Content \\
\hline 1 & Jembatan Merah Surabaya & $\begin{array}{l}\text { Historical analysis of the old city, JMP Plaza economics, } \\
\text { social interaction and multicultural life }\end{array}$ \\
\hline 2 & Lumpur Lapindo Sidoarjo & $\begin{array}{l}\text { Analysis of the causes and impacts of mudflow on } \\
\text { social, economic and environmental conditions. }\end{array}$ \\
\hline 3 & Ngoro Industry Area, Mojokerto & Analysis of industrial agglomeration. \\
\hline 4 & Trowulan site Mojokerto & $\begin{array}{l}\text { Analisis interdisiplin masa kerajaaan hindu-budha dan } \\
\text { pengaruhnya terhadap sosial, ekonomi dan budaya saat } \\
\text { ini. }\end{array}$ \\
\hline 5 & $\begin{array}{l}\text { Kabuh Rock Formation, } \\
\text { Jombang }\end{array}$ & $\begin{array}{l}\text { Geological and Geomorphological Analysis and } \\
\text { its influence on the agriculture of surrounding } \\
\text { communities. }\end{array}$ \\
\hline 6 & $\begin{array}{l}\text { Ngerong Cave and Rengel } \\
\text { Limestone Industry } \\
\text { Center, Tuban }\end{array}$ & $\begin{array}{l}\text { Geological and Geomorphological Analysis and } \\
\text { its influence on the agriculture of surrounding } \\
\text { communities. }\end{array}$ \\
\hline 7 & $\begin{array}{l}\text { Kembang Putih Museum and } \\
\text { the Tomb of SunanBonang } \\
\text { Tuban }\end{array}$ & $\begin{array}{l}\text { Interdisciplinary analysis of the period of Islamic } \\
\text { civilization and its influence on the economic, } \\
\text { social and cultural fields. }\end{array}$ \\
\hline
\end{tabular}

Locations which are used as outdoors laboratories are required to have content pedagogical in accordance with Social Studies Education. That way the learning objectives of social studies will be constructed through this outdoor laboratory learning activity. Of course some locations are dominated by Social studiesdisciplined content, such as history, geography, sociology and economics. Even so, the interdisciplinary approach will make each location an integrated learning (Dyment et al., 2018).

\section{Results and Discussion}

\subsection{Results of Implementation of Outdoor Learning Laboratory}

Stage in service learning 1, this is the first stage of the implementation of the Outdoor learning laboratory. The methods used in this activity are brainstorming, lecture, question and 
answer, analysis of Core Competencies (KI) - Basic Competencies (KD), Competency Achievement Indicators (GPA) and training on preparation of an outdoor learning Social Studies laboratory observation plan to be conducted. Exposure of material from the facilitator, presented through power point media regarding the provision of material at the Social Studies outdoor learning laboratory location. Through brainstorming, lectures and questions and answers, social studies teachers have the opportunity to reflect on and convey experiences they have experienced in the learning process that have been carried out by social studies teachers. The training material is given with the aim of giving the ability of Social Studies. Teachers to design the Outdoor learning laboratory for Social Studies material and to provide insights on the components that must be pursued to conduct an outdoor learning laboratory for Social Studies material. On this occasion the Social Studies teacher was also provided theoretical material related to the locations to be observed and analyzed in the northern part of East Java. Social Studies teachers also get introduced to the procedures and activities that will be carried out while in the outdoor learning laboratory.

Stage on the job learning, in this activity the teacher is accompanied and given the opportunity to make direct observations in the field (outdoor learning laboratory) in the northern part of East Java. The teacher is accompanied to see the potential of social studies learning in each location. The Social Studies teacher was accompanied by a team of researchers in carrying out field observations that were supplemented by field guides. Some of the areas chosen to be Social Studies outdoor learning laboratories are: 1) Surabaya Old Town in Jembatan Merah area; 2) Lumpur Lapindo, Sidoarjo; 3) Ngoro Industry Park Mojokerto; 4) Trowulan Site, Mojokerto; 5) Kaban Jombang Rock Formation; 6) Ngerong Cave and RengelTuban Limestone Industry; 7) Tomb of Sunan Bonang and Kambang Putih Museum ,Tuban. The Seventh Place is the locus center in Social Studies material that has been reviewed with an interdisciplinary approach.

Stage in service learning 2, at this stage the teacher returns to the room. Each teacher presented the results of Social Studies outdoor laboratory learning observation. The other teacher participants and the research team discussed and gave input to the teacher about the results of the Social Studies outdoor laboratory observation reports that had been produced. The teachers realize that the location which is used as an outdoor learning laboratory is very useful to be a source of learning for students. The implementation of outdoor learning laboratory activities is adjusted to the Competency Achievement Indicators (CAI) of Social Studies material in junior high schools, namely: Understanding the spatial aspects and connectivity between space and time in realizing the unity of the archipelago that includes the change and sustainability of Indonesian people's lives in pre-literate times, independence to the present. Understand the institutional benefits and foundation of social interaction dynamics in supporting the sustainability of people's lives.

\subsection{Teacher Evaluation of Program Implementation}

After carrying out a series of outdoor learning activities, it is very important to know the teacher's perspective on this program. Teachers were distributed questionnaires to find out the response related to usefulness, increased attention and motivation, and teacher satisfaction in carrying out practices in this outdoor learning laboratory. Table 3 reveals how teachers respond to the potential for social studies development through outdoor learning laboratories. 
Table 3. Response of the Implementation of Outdoor Learning Laboratory Against Social Studies Learning

\begin{tabular}{|c|c|c|c|c|}
\hline \multirow[b]{2}{*}{ Aspect } & \multicolumn{4}{|c|}{ Respon Guru (\%) } \\
\hline & $\begin{array}{c}\text { Strongly } \\
\text { agree }\end{array}$ & Agree & Not agree & $\begin{array}{c}\text { Strongly } \\
\text { not agree }\end{array}$ \\
\hline Makes social studies learning easier. & 81 & 15 & 3 & 1 \\
\hline $\begin{array}{l}\text { Provide a positive effect on the } \\
\text { benefits of social studies learning. }\end{array}$ & 91 & 9 & 0 & 0 \\
\hline $\begin{array}{l}\text { Social studies learning can take place } \\
\text { well without an outdoor learning } \\
\text { laboratory. }\end{array}$ & 24 & 16 & 45 & 15 \\
\hline $\begin{array}{l}\text { Outdoor laboratories can expand } \\
\text { social studies material. }\end{array}$ & 89 & 8 & 3 & 0 \\
\hline $\begin{array}{l}\text { The Outdoor Laboratory helps } \\
\text { students better understand social } \\
\text { studies subjects that are difficult to } \\
\text { understand. }\end{array}$ & 80 & 15 & 5 & 0 \\
\hline $\begin{array}{l}\text { Outdoor Laboratory does not add } \\
\text { Social Studies subject matter. }\end{array}$ & 6 & 16 & 34 & 44 \\
\hline
\end{tabular}

There are six items in the Likert scale to determine the teacher's response to the effects of the outdoor learning social studies laboratory on learning. The results are shown in Table 3. Almost all participants (81\%) stated the Social Studies outdoor learning laboratory had a positive effect on "making learning easier". In addition, most of them (91\%) stated that Social Studies outdoor learning laboratories had a "positive effect on learning benefits". They also stated that the Social Studies outdoor learning laboratory expanded Social Studies material $(89 \%)$ and helped students better understand difficult social studies subjects (80\%). In addition, teachers (45\%) stated that they did not agree that without using Social Studies outdoor learning laboratories as a learning environment was better and also $44 \%$ of them stated strongly disagree with the statement "Social Studies outdoor learning laboratories did not improve social studies learning material".

It is also important to know how the teacher's perspective is related to the potential for increased motivation and attention when implementing outdoor learning. When the response to this program is good, it can be used as consideration for developing laboratories in the northern region of East Java as a social learning center locus. Table 4 shows the response.

Table 4. Response to The Use Of Social Studies Outdoor Learning Laboratories Towards Attention And Motivation.

\begin{tabular}{lcccc}
\hline \multicolumn{1}{c}{ Aspect } & \multicolumn{3}{c}{ Teachers' Responses (\%) } \\
\cline { 2 - 5 } & $\begin{array}{c}\text { Strongly } \\
\text { agree }\end{array}$ & Agree & Not agree & $\begin{array}{c}\text { Strongly } \\
\text { not agree }\end{array}$ \\
\hline $\begin{array}{l}\text { Learners become passive during outdoor } \\
\text { learning laboratory activities. }\end{array}$ & 6 & 16 & 24 & 54 \\
$\begin{array}{l}\text { Outdoor learning laboratories do not increase } \\
\text { interest in social studies subjects. }\end{array}$ & 0 & 0 & 27 & 63 \\
$\begin{array}{l}\text { Outdoor learning laboratories provide } \\
\text { opportunities to engage in learning. }\end{array}$ & 57 & 26 & 13 & 0 \\
$\begin{array}{l}\text { The outdoor learning laboratory increases the } \\
\text { concentration of learning. }\end{array}$ & 88 & 9 & 2 & 1 \\
$\begin{array}{l}\text { Students' outdoor learning laboratories are } \\
\text { more motivated. }\end{array}$ & 78 & 17 & 4 & 1 \\
$\begin{array}{l}\text { The outdoor learning laboratory makes the } \\
\text { material more concrete. }\end{array}$ & 90 & 9 & 1 & 0 \\
\hline
\end{tabular}


There are six items in the Likert scale to determine teacher perceptions about how the application of Social Studies outdoor learning laboratories influences students' attention and motivation. The results are shown in Table 4. When the results are examined, it can be clearly seen that the teacher believes that when the Social Studies outdoor learning laboratory is used, students become more motivated in the lesson (78\%), increase the concentration of the lesson $(88 \%)$, and make the material more concrete (90\%). On the other hand, they strongly disagree with the idea that "not increasing interest" (63\%) and "passive learners" (54\%).

After the teacher fills in the questionnaire response regarding the influence of the Social Studies outdoor learning laboratory on learning, interest and motivation then collects and manages the teacher's response data to the social learning laboratory activities that have been carried out. The following is the level of teacher satisfaction response to Social Studies outdoor learning laboratory activities and the results of discriminant analysis to determine the effect of outdoor learning activities.

Table 5. Response and Discriminant Analysis

\begin{tabular}{|c|c|c|c|c|}
\hline No & Aspect & Response (\%) & Wilks' Lambda & $P$ value \\
\hline 1 & Fun & 72,5 & 0,553 & 0,001 \\
\hline 2 & Effective & 75 & 0,524 & 0,001 \\
\hline 3 & Efficient & 50 & 0,921 & 0,229 \\
\hline 4 & Complicate & 52,5 & 0,996 & 0,793 \\
\hline 5 & Contextual & 71,25 & 0,453 & 0,000 \\
\hline
\end{tabular}

Table 5. shows that the Social studies outdoor laboratory learning activities are considered as fun programs, effective programs and contextual programs in social studies learning ( $p=0.01 ; 0.001$; and $000<0.05)$. While Social studies outdoor learning laboratory activities are considered to be in efficient programs and difficult programs $(p=0.229$ and $0.793>0.05$ ). The Wilks Lambda test results also showed that there were significant differences between the five activities of the Social studies outdoor learning laboratory program in the discriminant model with a $p$ value of 0.07 .

\section{a. The Difficulties of Teachers to Utilize Outdoor Learning Laboratories}

More than half of teachers find it difficult to use outdoor learning laboratories practiced in social studies classes. Based on these results, it is very necessary to find out the constraints that these social studies teachers care about. In-depth interviews were conducted to reveal the perception of the teacher's difficulties in using outdoor laboratories. The results can be summarized in the following table 6.

Tabel 6. Results of Identifying Teacher Difficulties in Utilizing Outdoor Laboratories Learning

\begin{tabular}{ll}
\hline \multicolumn{1}{c}{ Difficulties } & \multicolumn{1}{c}{ Deskripsi } \\
\hline Time & $\begin{array}{l}\text { Social studies teachers in Surabaya feel that time will become an obstacle if they } \\
\text { utilize outdoor learning laboratories. This will be difficult if done in the middle of } \\
\text { normal study hours. The teacher feels the right time for this is by conducting a } \\
\text { study tour or fieldtrip. }\end{array}$ \\
Transportation & $\begin{array}{l}\text { Transportation to the location of the outdoor learning laboratory is one of the } \\
\text { difficulties, not all schools have institution-owned transportation, so if you use } \\
\text { transportation from outside, it requires costs and also coordination with }\end{array}$ \\
Teaching & $\begin{array}{l}\text { otherparties. } \\
\text { material }\end{array}$ \\
Social studies learning that utilizes outdoor laboratories is very necessary to make \\
a teaching material or worksheet. This is an obstacle because the making of \\
teaching materials or worksheets requires time and a careful planning process, \\
to suit the objectives and learning needs. \\
Students who take part in learning in outdoor Laboratory will need additional fees \\
charged to students. The teacher is worried that if the program is implemented it \\
will burden students.
\end{tabular}




\begin{tabular}{cl}
\hline Difficulties & \multicolumn{1}{c}{ Deskripsi } \\
\hline Coordination & $\begin{array}{l}\text { Social studies teachers teach several classes in eachjuniorhighschool level, so if } \\
\text { you use an outdoor laboratory it is necessary to coordinate with other social } \\
\text { studies teachers as students' facilitators. The number of students that is quite a } \\
\text { lot will not be comparable with the Social Studies teachers available inschools. }\end{array}$ \\
\hline
\end{tabular}

Time planning is one of the obstacles in the use of outdoor learning. The use of appropriate time according to Social studiesteachers in Surabaya is done outside of scheduled study hours. However, it must also adjust to the academic calendar, so that the time is right with the educational agenda. The concept of field trip social studies becomes one of the solutions, but this activity cannot be done every time, it requires careful planning of activities, especially those related to technical problems. Transportation and costs become difficulties faced by teachers to carry out learning outside the classroom. Based on the experience experienced by the teacher, it is quite difficult to collect costs for activities outside the classroom. Parents of students also often express their objections.

In addition to technical problems, problems related to pedagogical teachers also arise. Teaching material in the use of outdoor learning becomes important. Students are expected to have adequate teaching materials or worksheets, so that the learning process is in line with expectations. Worksheet details must be considered and adjusted to the learning object and the objectives of social studies learning. This linkage becomes the difficulty of the teacher in preparing teaching materials or worksheets. Factual knowledge and skills in transforming values are also needed to make sense of a place at an outdoor laboratory site or location.

\section{b. Discussion}

According on the results of data processing shows that Social Studies outdoor learning laboratory activities have a positive response for social studies teachers because they are considered: 1). make learning easier, 2). positive effect on the benefits of learning, 3). expanding Social Studies material, 4). help students better understand subjects that are difficult to understand. This is like the findings of previous research which stated that learning outside the classroom gives students as much opportunity as possible to get direct experience of observing and studying material in real life so that learning outcomes are more optimal (McClain C \& M, 2015; Oloumia .S \& A, 2012; Waters \& Maynard, 2010). Outdoor learning presents a challenge for students to be able to develop their ideas more broadly about phenomena in the environment as a result of interactions between nature and humans.

Activities that use learning media are more concrete or with direct experience so messages (information) in the learning process delivered by the teacher to students will be conveyed properly. But conversely if the use of instructional media becomes more abstract then the message (information) will be difficult for students to accept, in other words they face difficulties in understanding or digesting what is conveyed by the teacher. As expressed by Dale (1969), symbols and ideas can be more easily understood and absorbed when given in the form of concrete experiences.

The results of data processing showed that Social Studies outdoor learning laboratory activities had a positive response to increased attention and learning motivation. Through social studies outdoor learning laboratories, learning can activate students, the material becomes more concrete, and increases the concentration of learning. This is reinforced by research findings that say outdoor learning by utilizing the natural environment can increase learning motivation, attention and learning concentration (Bell, 2005; Sukma Perdana Prasetya, 2014). Affective will also affect the interests and participation of students in the learning process (Focht, 2009).

There are several obstacles that must be given a solution so that outdoor laboratory learning can be maximized. The results showed that there were five things that became a problem in the implementation of this activity, namely: 1) time; 2) Transportation; 3) teaching materials; 4) Costs and 5) Coordination. The problem of actual time can be overcome by doing careful planning every school year. Actually, this activity does not have to be carried out 
specifically, but can be followed by other programs. If you follow other programs, then other problems will also be resolved, so that outdoor laboratories can be realized and become a routine agenda in social studies learning.

The satisfaction response revealed that respondents were satisfied with the Social Studies outdoor learning laboratory activities. This happens because they consider the program to support social studies that are fun, effective and contextual. Learning is fun because students in studying social studies do not just accept theories but there is an element of recreation in observing the actual environment. Students can demonstrate and examine the diversity of unique and beautiful environmental phenomena as a result of the interaction of nature with humans. In outdoor learning activities there is always a new atmosphere, new experiences, and practical experiences so that learning is not boring.

Learning is contextual because the area used as a laboratory is the northern part of East Java, where the area is close to social studies teachers in East Java so that the area is not too foreign to be studied more deeply. According to Miller, (2017), outdoor learning becomes a concept that is more easily adopted by educators to explain contextual content (eg. Social Studies) that they have used to design learning experiences for students. Outdoor learning activities will also be very effective if carried out in a structured manner with careful planning (Thomas \& Thomas, 2018). For example, students can go to the forest to learn about the dynamic relationshipSocial Studiesbetween various flora and fauna or take a trip to a local historic site to learn about important historical events, and see how the landscape of the earth affects the economic activities of the population.

Learning must be supported by indoor and outdoor activities that contribute to the structuring of knowledge (Yıldırım \& Akamca, 2017). Outdoor learning involves practical activities and experiences that are carried out outdoors in the school grounds and in nearby locations that have high educational value. Experts also argue that learning can be curricular, cognitive and related to the context of indoor learning (Atencio et al., 2015). In outdoor laboratory learning learning by utilizing the environment is very important for social studies learning (Prasetya, 2018). Broadly speaking the benefits of the laboratory in the learning process are as follows (a) as a place to practice developing intellectual skills through observing, recording and assessing symptoms in the environment, (b) developing motor skills. Students will increase their skills in using available field observation instruments to search for and find truth, (c) give and foster the courage to seek the essence of scientific truth of an object in the natural and social environment, (d) foster student curiosity as a capital for scientific attitudes a prospective scientist, (e) fostering confidence as a result of skills and knowledge, research.

Utilization of outdoor laboratories in learning can also be done with a group investigation model. This model will be able to simplify because environmental exploration is carried out in groups, so that the process of interaction with fellow students will be established and social interaction to collaborative work will emerge. Through authentic investigations students can investigate the natural world, propose ideas, and explain and justify statements based on evidence and, in the process, will feel the spirit of science (Hofstein \& Lunetta, 2003; Hume \& Coll, 2008). Group investigation allows students to be directly involved in the way they acquire knowledge, students not only as recipients of information (Mitchell, Montgomery, Holder, \& Stuart, 2008). Learning outcomes will also be satisfactory if students conduct group investigations in the surrounding environment (Lim, Kim, Chen, \& Ryder, 2008). Through group investigations will make motivation, learning achievement and also students' perceptions in learning increase (Tan, Sharan, \& Lee, 2010). It is possible if the outdoor laboratory can be integrated with the group investigation learning process in social studies subjects, resulting in high demands, motivation and learning achievement.

The Social Studies outdoor learning laboratory is effectively implemented because in analyzing a phenomenon in the field it is always studied in an integrated manner with an interdisciplinary approach. For example, when examining the phenomenon of Majapahit's tenure in Trowulan, not only were the descriptions of historical events examined, but also how the economic activities of the population at that time were predominantly farmers. This agricultural activity is supported by geographical factors where the location of the Majapahit 
kingdom lies on the fertile slopes of the Arjuno Mountains and many water sources. Sociology review is also studied how the life of the people who are united, harmonious and united, this can be proven by the popular motto "Bhineka Tungal lka" in the book of Sutasoma by Empu Tantular who lives in the mass of the Majapahit kingdom. A glorious view of Majapahit culture can also be seen from various relics that still survive such as various temples (Tikus temple, Bajang Ratu temple, Bentar Temple), various literary works (Negara Kertagama, Pararaton), Beber puppets and Reog art are Majapahit relics in the arts. Through the analysis of environmental conditions with outdoor learning laboratories, it can be explored how all forms of population efforts from time to time have used all the opportunities that have been presented to the environment to humans. Variations in types of environment can trigger differences in the level of human adaptation in managing the environment. Environmental conditions in a region can testify about the sinking of a civilization's society. For example the impact of environmental disasters floods, droughts, landslides, tsunamis, earthquakes, erosion, forest fires, and volcanic eruptions can change the characteristics of the area which was originally a central civilization into a marginalized area (White, 2012).

The most important thing is that social studies teachers are still looking for strategies and tools to help students prepare for life outside the classroom. In conclusion, valuable lessons must be learned from the initial development of outdoor laboratories. Space, technology and innovative ideas are meaningless unless they are accompanied by a commitment to move toward student-centered and learning activities. Although technology access becomes inevitable, laboratories will become learning strategies that empower students to use, develop and criticize technologies that substantive learning takes place in social studies learning (Mauch, 2010). In addition, outdoor laboratories have been shown to be highly predicting of students' attitudes and achievements, this provides important information to teachers who want to optimize the laboratory learning environment in developing student learning outcomes (Fisher et al., 1988; Halim, 2009).

\section{Conclusions and Suggestions}

The implementation of outdoor learning laboratory activities can run well. Social Studiess Surabaya teachers can follow all stages of learning starting from the stages in service learning 1, on the job training and in service learning 2. The Social Studies outdoor learning laboratory can provide new experiences involving students to connect between natural variables and human culture so that certain phenomena are formed.

The teacher's response was very positive towards the implementation of social studies outdoor learning laboratory because it can facilitate social studies learning, expanding social studies material, and is useful in mastering Social Studies material that is difficult to understand because outdoor learning laboratories provide material that is contextual and relevant to real-world conditions. Teacher responses also consider it important to use outdoor learning laboratories to improve social studies learning outcomes because a real learning environment will bring learning experiences from abstract to concrete so that social studies material is easier to master.

The response to the satisfaction of the teacher in the Social Studiesoutdoor learning Laboratory Activity is a fun, effective and contextual program. The motivation and attention of social studies teachers in the implementation of outdoor learning laboratories also largely received positive responses. Through outdoor learning laboratories, teachers can increase motivation, attention and concrete experience in social studies learning. The outdoor learning laboratory program is inefficient related to the amount of time and cost, while to implement it is not easy, it requires field experience so that the teacher can fully master the Social Studies material. By collecting and utilizing various data that has been directly observed in the field, social studies learning becomes more extensive and meaningful. The group investigation model can be an alternative learning process in an outdoor laboratory. In addition, this program will be very effective if done with the preparation of activity guides, learning guides, student worksheets and material guides that are appropriate to the needs of students and learning objectives. 


\section{References}

Acar, H. (2013). Assessment of natural landscape elements' play affordances, (In Turkish: Doğal peyzaj elemanlarının oyun olanaklııklarının değerlendirilmesi). Karadeniz Technical University.

Amineh, R. J., \& Asl, H. D. (2015). Review of Constructivism and Social Constructivism. Journal of Social Studiess, Literature and Languages, 1(1), 9-16.

Atencio, M., Sze, Y., Tan, M., Ho, S., Ching, C. T., Atencio, M., ... Ching, C. T. (2015). The place and approach of outdoor learning within a holistic curricular agenda : development of Singaporean outdoor education practice. Journal of Adventure Education and Outdoor Learning ISSN:; $\quad 15(3), \quad 181-192$. https://doi.org/10.1080/14729679.2014.949807

Bakhurst, D. (2015). Understanding Vygotsky. Learning, Culture and Social Interaction, 5, 14. https://doi.org/10.1016/j.lcsi.2014.06.001

Bell, P. (2005). The school science laboratory: Considerations of learning, technology, and scientific practice. National Academy of Sciences.

Boaventura, D., Faria, C., Chagas, I., \& Galvão, C. (2013). Promoting Science Outdoor Activities for Elementary School Children: Contributions from a research laboratory. International Journal of Science Education, 35(5), 796-814. https://doi.org/10.1080/09500693.2011.583292

Brophy, J., \& Alleman, J. (2009). Meaningful social studies for elementary students. Teachers and Teaching, 15(3), 357-376. https://doi.org/10.1080/13540600903056700

Byrd, R. K., Haque, M. T., Tai, L., McLellan, G. K., \& Knight, E. J. (2007). Designing a children's water garden as an outdoor learning lab for environmental education. Applied Environmental Education and Communication, 6(1), 39-47. https://doi.org/10.1080/15330150701319859

Campbell, T., \& Bohn, C. (2018). Social-Science Laboratory Experiences of High School Students Across One State in the U.S.: Descriptive Research from the Classroom. Science Educator, 17(1), 36-48.

Castro, A. J., \& Knowles, R. T. (2015). Social Studies Education. In International Encyclopedia of the Social \& Behavioral Sciences (Second Edi, Vol. 22, pp. 727-734). Elsevier. https://doi.org/10.1016/B978-0-08-097086-8.92090-7

Churcher, K. M. A., Downs, E., \& Tewksbury, D. (2014). “Friending " Vygotsky: A Social Constructivist $P$ edagogy of Knowledge Building Through Classroom Social Media Use, 14(1), 33-50.

Cook, K. S. (2008). Laboratory Experiments in the Social Studiess. Contemporary Sociology, 37 (9), 37(9), 602-604.

Dale, E. (1969). Audio Visual Methods in Teaching. New York: Dryden Press.

Dewey, J. (1951). Experience and education. New York: Macmillan.

Dyment, J. E., Chick, H. L., Walker, C. T., Thomas, P. N., Dyment, J. E., Chick, H. L., ... Macqueen, T. P. N. (2018). Pedagogical content knowledge and the teaching of outdoor education education. Journal of Adventure Education and Outdoor Learning, 00(00), 120. https://doi.org/10.1080/14729679.2018.1451756

Fisher, D., Harrison, A., \& Henderson, D. (1988). Laboratory Learning Environments and Practical Tasks in Senior Secondary Science Classes. Research in Science Education, 28(3), 353-363.

Focht, B. C. (2009). Brief walks in outdoor and laboratory environments: Effects on affective responses, enjoyment, and intentions to walk for exercise. Research Quarterly for Exercise and Sport, 80(3), 611-620. https://doi.org/10.1080/02701367.2009.10599600

Francis, C. (2017). Particular places: School environments over time. In Landscapes for Learning: Creating Outdoor Environments for Children and Youth (pp. 45-87). New York: John Wiley\&Sons, Inc.

Halim, L. (2009). Improving science literacy through a conducive laboratory learning environment: a proposed model. In In international conference on science and mathematics education.

Henderson, W., \& Aginsky, B. W. (1941). A Social Studies field laboratory. American 
Sociological Review, 6(1), 41-44.

Hofstein, A., \& Lunetta, V. (2003). The laboratory in science education: Foundations for the twenty-first century. Science Education, 88(1), 28-54.

Hume, A., \& Coll, R. (2008). Student experiences of carrying out a practical science investigation under direction. International Journal of Science Education, 30(9), 12011228.

Karppinen, S. J. A. (2012). Outdoor adventure education in a formal education curriculum in Finland: action research application. Journal of Adventure Education and Outdoor Learning, 12(1), 41-62.

Kellert, S. R. (2002). Experiencing nature: Affective, cognitive, and evaluative development in children. Children and nature. In Psychological, sociocultural, and evolutionary investigations (pp. 117-151).

Kolb, D. A. (1984). Experiential learning. Englewood Cliffs: NJ: Prentice-Hall.

Levitt, S. . a, \& List, J. A. (2017). What Do Laboratory Experiments Measuring Social Preferences Reveal About the Real World?. Journal of Economic Perspectives. 21(2)., 21(2), 153-174.

Lim, J., Kim, M., Chen, S. S., \& Ryder, C. E. (2008). An Empirical Investigation of Student Achievement and Satisfaction in Different Learning Environments. Journal of Instructional Psychology, 35(2), 113-119.

Loebach, J. (2004). Designing learning environments for children: An affordance-based approach to providing developmentally appropriate settings. Dalhousie University, Halifax.

Mauch, J. (2010). A Historical Approach To Social Studies Laboratory Method. Research in Social Studiess and Technology, 1(2), 55-66.

McClain C, \& M, V.-P. (2015). Social contexts of development in natural outdoor environments: children's motor activities, personal chal- lenges and peer interactions at the river and the creek. Journal Adventure Education Outdoor Learning, 16(1), 31-48.

Miller, B. . (2017). Outdoor Learning. In The SAGE Encyclopedia of Out of School Learning. Thousand Oaks.

Mitchell, M. G., Montgomery, H., Holder, M., \& Stuart, D. (2008). Group Investigation as a Cooperative Learning Strategy: An Integrated Analysis of the Literature. The Alberta Journal of Educational Research, 54(4), 388-395.

Oloumia .S, M. M., \& A, N. (2012). Evaluation of Outdoor Environment from the Viewpoint of Children. Procedia - Social and Behavioral Sciences, 35(1), 431-439.

Prasetya, S.P. (2018). Lingkungan Geografis Sebagai Sumber Dan Media Pembelajaran IImu Pengetahuan Sosial. In Prosiding Seminar Nasional APRIPSI. Banjarmasin: Universitas Lambung Mangkurat.

Prasetya, Sukma Perdana. (2014). Media Pembelajaran Geografi. Yogyakarta: Ombak.

Singer, A. J. (2003). Social Studies for Secondary Schools Teaching to Learn, Learning to Teach. New Jersey: Lawrence Erlbaum Associates, Inc., Publishers.

Sujarwo, S., Samsi, I., \& Wibawa, L. (2017). Desain model wisata belajar di Kebun Binatang Gembiraloka Yogyakarta sebagai laboratorium luar kampus. Jurnal Pendidikan Dan Pemberdayaan Masyarakat, 4(1), 90. https://doi.org/10.21831/jppm.v4i1.12535

Tan, I. G. C., Sharan, S., \& Lee, C. K. E. (2010). Group Investigation Effects on Achievement, Motivation, and Perceptions of Students in Singapore. The Journal of Educational Research, 100(3), 142-154. https://doi.org/10.3200/JOER.100.3.142-154

Thomas, G. J., \& Thomas, G. J. (2018). Effective teaching and learning strategies in outdoor education: findings from two residential programmes based in Australia fi ndings from two residential programmes based in Australia. Journal of Adventure Education and Outdoor Learning, OO(00), 1-14. https://doi.org/10.1080/14729679.2018.1519450

Waters, J., \& Maynard, T. (2010). What's so interesting outside? A study of child-initiated interaction with teachers in the natural outdoor environment. European Early Childhood Education Research Journal, 18(4), 473-483.

Webster, M., J., \& Sell, J. (2014). Laboratory experiments in the Social Studiess (2nd ed.). Elsevier Academic Press. 
Westley, F., Goebey, S., \& Robinshon, K. (2010). Change Lab/Design Lab for Social Innovation. Waterloo Institute of Social Innovation and Resilience. Waterloo Institute of Social Innovation and Resilience.

White, G. F. (2012). Geography. Encyclopaedia of Global Environmental Change, 3(1), 337.

Yıldırım, G., \& Akamca, G. . (2017). The effect of outdoor learning activities. South African Journal of Education, 37(2), 1-10. 